\title{
ACÉLSZERKEZETEK TERVEZÉSE ÉS SZÉLSZIMULÁCIÓJA PARAMETRIKUS KÖRNYEZETBEN
}

\section{DESIGN AND WIND SIMULATION OF STEEL STRUCTURES IN A PARAMETRIC ENVIRONMENT}

\author{
Kis Ádám, ${ }^{1}$ Nagy Andor Csongor ${ }^{2}$ \\ ${ }^{1}$ Kolozsvári Müszaki Egyetem, Építőmérnöki Kar, Kolozsvár, Románia, Adam.Kis@student.utcluj.ro \\ ${ }^{2}$ Kolozsvári Müszaki Egyetem, Építőmérnöki Kar, Kolozsvár, Románia, andor.nagy@yahoo.com
}

\begin{abstract}
Nowadays, parametric design and various simulation methods are gaining ground in almost every engineering and creative profession. This paper investigates the practical applicability of the combination of these methods, by analysing a specific free-form structure with Grasshopper 3D and OpenFOAM and points out the differences between the results of a CFD simulation and the recommended methods of the Eurocode, highlighting the new perspectives that are opening up in the field of structural design, especially in the examination of wind effects.
\end{abstract}

Keywords: parametric structural design, wind simulation, computational fluid dynamics.

\section{Összefoglalás}

Napjainkban gyakorlatilag minden mérnöki és alkotói szakmában egyre nagyobb teret hódít a parametrikus tervezés és a különböző szimulációs módszerek. A tanulmány ezen módszerek kombinálásának gyakorlati alkalmazhatóságát kutatja egy szabadformájú szerkezet vizsgálata során (Grasshopper 3D és OpenFoam szoftverek használatán keresztül), kiemelve a szimuláció, illetve az Eurocode által javasolt módszerek eredményei közötti különbségeket. Továbbá bemutatja, hogy milyen új távlatok nyílnak meg a szerkezettervezés terén, különös tekintettel a szélhatások vizsgálata esetén.

Kulcsszavak: parametrikus tartószerkezet-tervezés, szélszimuláció, numerikus folyadékdinamika.

\section{Bevezetés}

A hagyományos tervezés, a különböző szabványok figyelembevétele/alkalmazása esetén rengeteg, empirikus úton bevezetett biztonsági tényező és statisztikai megközelítés használatán alapul. Ennek következtében gyakran a vizsgálandó épületek geometriai kialakítása, illetve a rá ható terhek olyan szinten változhatnak az egyszerűsítések következtében - kiváltképp, ha a szerkezet geometriája szabadformájú, melyet a szokásos eszköztárral gyakorlatilag lehetetlen pontosan modellezni és ezáltal elemezni, hogy a valóságtól való elrugaszkodás jogos aggodalmat okozhat egy szerkezettervező számára.
Pedig a jelenkor építészetének fő vonásaihoz tartozik a merész, mégis könnyednek ható formavilág, egyre gyakrabban találkozhatunk úgynevezett free-form (szabadformájú) szerkezetekkel, melyek komoly szakismeretet igénylő feladatokkal látják el a szerkezettervező mérnököket.

Mérnökileg megfontoltan, de tudni kell reagálni a fent említett igényekre is. Egy parametrikus környezet azonban segítséget nyújt a mérnök számára egy kontrollálható modell megalkotásában. A Rhino 3D nevű CAD szoftverbe beépülő Grasshopper modul talán a legrugalmasabb ilyen típusú modellező eszköz [1]. A saját vizuális programozói nyelve lehetővé teszi az úgynevezett algoritmikus modellezést, mely manapság kulcs- 


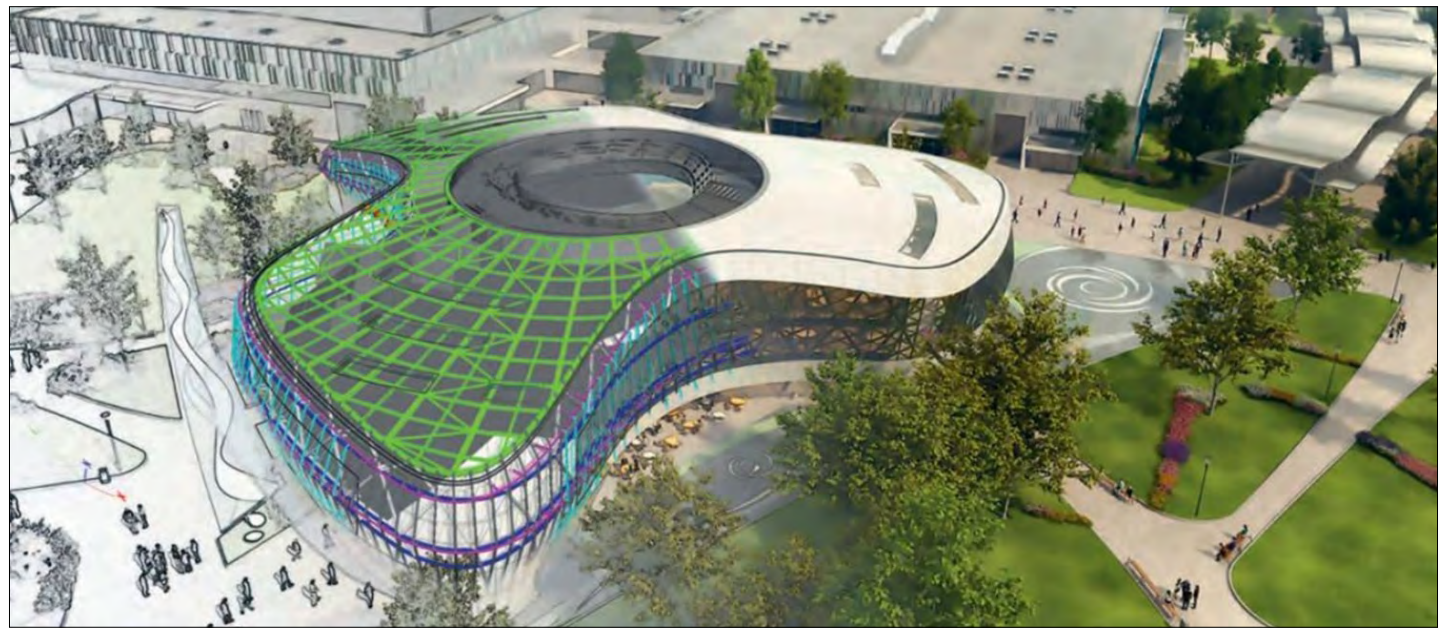

1. ábra. A budapesti Hungexpo Kongresszusi és Kiállítási Központ fogadóépületének statikai rúdvázmodellje (bal oldal) és építészeti látványterve (jobb oldal)

fontosságú bizonyos tervezési folyamatok hatékonyságnövelésének szempontjából.

$\mathrm{Az}$ 1. ábrán is látható acélszerkezet tervezésekor, a statikai rúdvázmodell kialakításától és analizálásától kezdve, a főszerkezet és a másodlagos, burkolati szerkezet gyártmánytervezésén át egészen a gyártás- és szereléstámogatásig, gyakorlatilag mindenhol bevethető volt és nagymértékű hatékonyságot mutatott a parametrikus rendszerszintű gondolkodás [2, 3], melyet a tanulmány bővebben taglal a továbbiakban. A szerkezetre ható terhek vizsgálatakor szélszimulációs módszerek használatára is sor került, amelyek a fő témáját képezik a tanulmánynak. Általánosságban azonban kijelenthetjük, hogy a fenti módszerek/eszközök, elsősorban a szimulációk, a többi iparággal ellentétben, korántsem elterjedtek az építőiparban, főleg nem a szerkezettervezők esetében. Pedig a 2D-s, majd 3D-s modellezői technikák után ebben rejlik talán a legnagyobb kiaknázatlan potenciál a szerkezettervezés jövőjét tekintve.

\section{A vizsgált acélszerkezet parametri- kus tervezésének rövid bemutatása}

A vizsgált épület a funkcionalitását tekintve a Budapesti Kongresszusi és Kiállítási Központ irodahelyiségekkel és bemutatótermekkel ellátott fogadócsarnoka. A rácsszerkezetű homlokzat egyediségét a háromszintes, eltérő alapterületű beton tartószerkezethez való igazodása adja, míg a tetőszerkezet különleges alakját a gömbfelületre illeszkedés biztosítja.

Általánosságban a parametrikus tervezés egy megfontoltan felépített szabályrendszerű kódsort igényel (2. ábra). Ehhez pedig mindenekelőtt a bizonyos korlátok és szélsőséges esetek meghatározása és az alapvető koncepcionális elvek tisztázása szükséges, azaz a paraméterek leszögezése. Ezt követi az adatok feldolgozása, mely jelenthet méretezést, modellezést vagy éppen gyártmánytervezést.

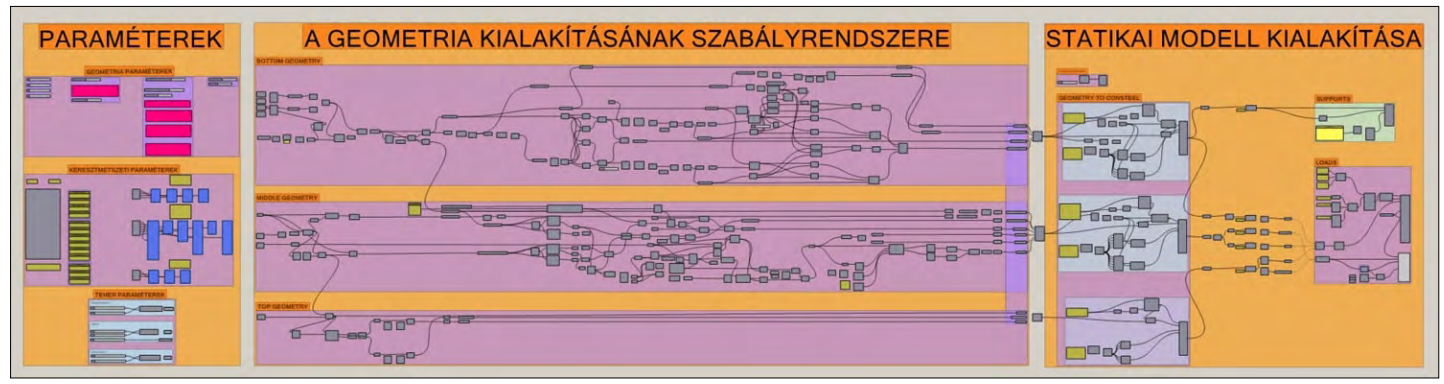

2. ábra. Példa egy Grasshopperben kialakított parametrikus kódsorra 


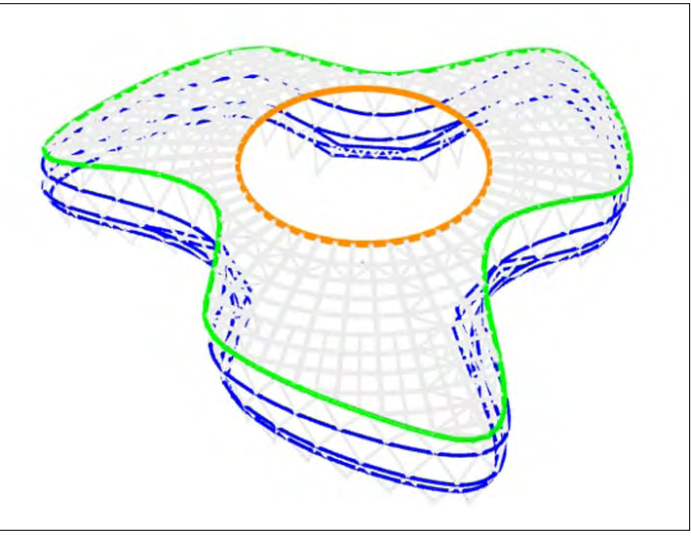

3. ábra. A végleges statikai rúdvázmodell, színekkel kiemelve az építészeti alapgeometria

Építészeti oldalról a tervezett acélszerkezet geometriája alapvetően a következő rögzített elemekhez igazodik, tehát ezek szerint rendeződik későbbiekben a teljes szerkezet (3. ábra):

- a forgásszimmetrikus, magasságilag konstans, szintenként eltérő homlokzati peremgyürű (kék);

-szintén forgásszimmetrikus, de a gömbfelületre illeszkedés következtében magasságilag eltérő, külső tető peremgyürü (zöld);

- vízszintes, kör alakú, belső peremgyürü (narancssárga).

Tartószerkezet-tervezői oldalról tehát a geometriai korlátok mellett kell igazodni a tartószerkezet teherbírási, gyárthatósági és szerelhetőségi korlátaihoz. A bemutatott tetőszerkezet teherhor-

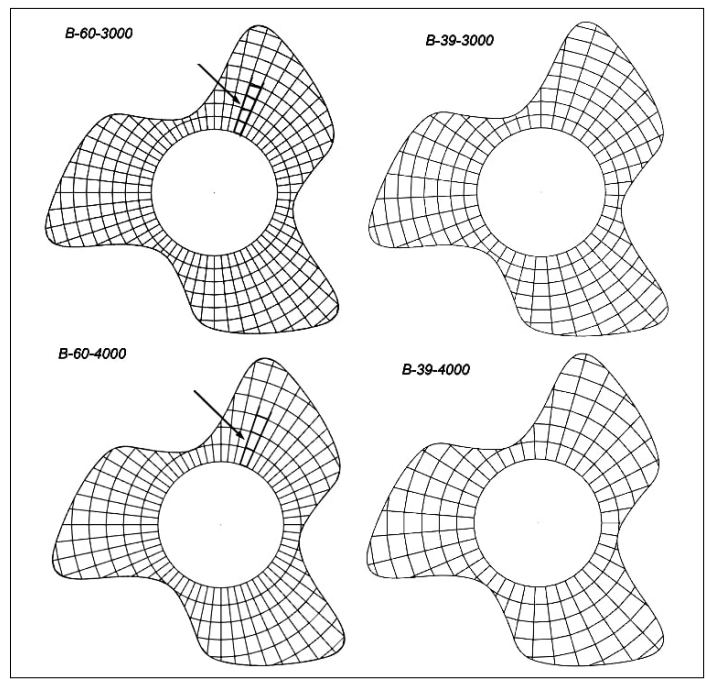

4. ábra. Tetőszerkezet-kiosztás koncepciók. Sugárirányú tartókkal dási rendszerének kialakítása, azaz a rácsozása és szegmentálása így a szerkezettervező mérnök elsődleges feladata volt a teljes acélszerkezet globális statikai ellenőrzései és a csomópontok számításai mellett. Több szerkezeti kialakítás (4. és 5. ábra) is felmerült, ezek vizsgálata szintén parametrikus úton történt [4] a következő szempontok szerint: össztömeg, teherbírás, stabilitás, lehajlás és a csomóponti komplexitás (egyedi és típuscsomópontok száma).

A vizsgálatokat követően kialakult a végleges tetőszerkezet, ahol a külső és a belső peremgyürűket radiális síkban ívesített főtartók kötik össze, melyek hagyományos kéttámaszú tartóként viselkednek. A főtartókat egymás között koncentrikus körök formájában egyenes szegmensű nyomórudak kötik össze. A kialakuló mezők helyenként merevítésekkel és másodlagos radiális tartókkal vannak megerősítve.

Összességében tehát a szerkezet tervezése során a Grasshopperben folytatott munka kiemelt fontossággal bírt, ugyanis általa vált vezérelhetővé a teljes munkafolyamat, ahol a kulcs a tervezést segítő szoftverek összehangolása/összekapcsolhatósága (6. ábra). Ebben az adatáramláson alapuló tervezési munkafolyamatban a Grasshopper mint gócpont biztosította a bemenő adatokat előméretezéskor (Karamba bővítmény), a statikai vizsgálatok során (ConSteel), a csomóponti méretezéskor (IDEA Statica), a gyártmánytervezéskor (Tekla Structures) és a szélszimulációk elvégzése során is (OpenFOAM).

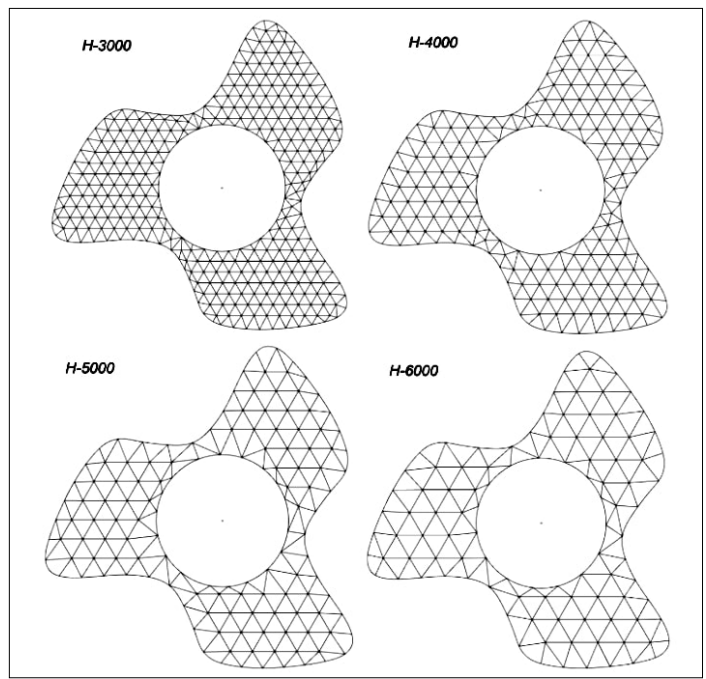

5. ábra. Tetőszerkezet-kiosztás koncepciók. Háromszögrácsozás 


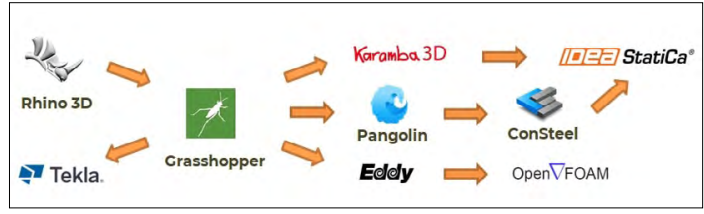

6. ábra. Tervezési folyamatábra

\section{A szélteher felvétele szabvány szerint}

A szerkezetre ható szél erőssége a szél átlagos sebességéből és az épületet körülvevő áramlási közegben, a szél hatására fellépő turbulencia által generált, fluktuáló szélerősség alapján számítható [5]:

$$
V(z, t)=v_{m}(z)+v(z, t)
$$

Az EN-1991-1-4 [6] szabvány viszont a tartószerkezeteket érő szélhatások számításához a szél által generált igénybevételeket egyszerűsített felületi nyomásokként határozza meg, figyelembe véve a szerkezet alakját, elhelyezkedését, a terep egyenetlenségét stb. Ezáltal a szélhatás egy kvázistatikus hatásként vehető figyelembe, mely megegyezik a turbulens szél maximális sebességének hatásával.

$$
q_{p}(z)=\frac{1}{2} \rho v_{p}(z)^{2}
$$

Azaz a felületi nyomás a torlónyomás csúcsértékének („z” magasságban a talaj felett) és az épülethez tartozó alaki tényezők szorzatának eredményeképpen határozható meg, és szélnyomásként vagy szélszívásként hat a merevnek tekintett épület felületein:

$$
w_{e}=q_{p}\left(z_{\text {ref }}\right) \cdot c_{p e}
$$

A már bemutatott szerkezet esetén, a szabvány módszereit figyelembe véve, a fő kihívást értelemszerűen a megfelelő nyomási tényezők meghatározása jelenti. A tanulmány az egyszerűség kedvéért a külső nyomási tényezők meghatározására korlátozódik, melyek esetén a szabvány alapvetően több szabályos alakot is taglal: lapos tetők, különböző nyeregtetők, donga alakú tetők, kupolák stb. A szerkezet relatív alacsony tetőmeredekségéből adódóan „ráerőltethetőek” egy ívesen lekerekített lapostetőhöz tartozó nyomási tényezők, vagy akár egy nyeregtető nyomási tényezői is. A biztonság javára, az utóbbi esetet vizsgálva és egy $5^{\circ}$-os tetőnek megfelelő nyomási tényezőket figyelembe véve a szerkezeten a 7.ábrán látható nyomáseloszlás feltételezhető.

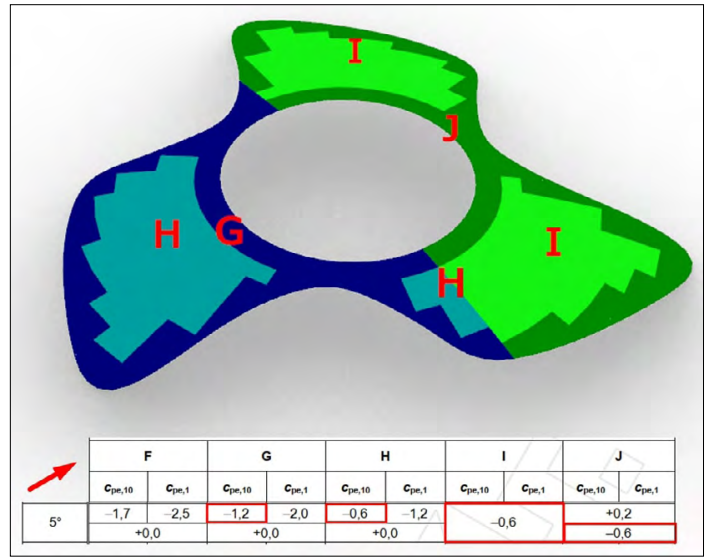

7. ábra. Nyomási tényezők a tetőn. 1. eset

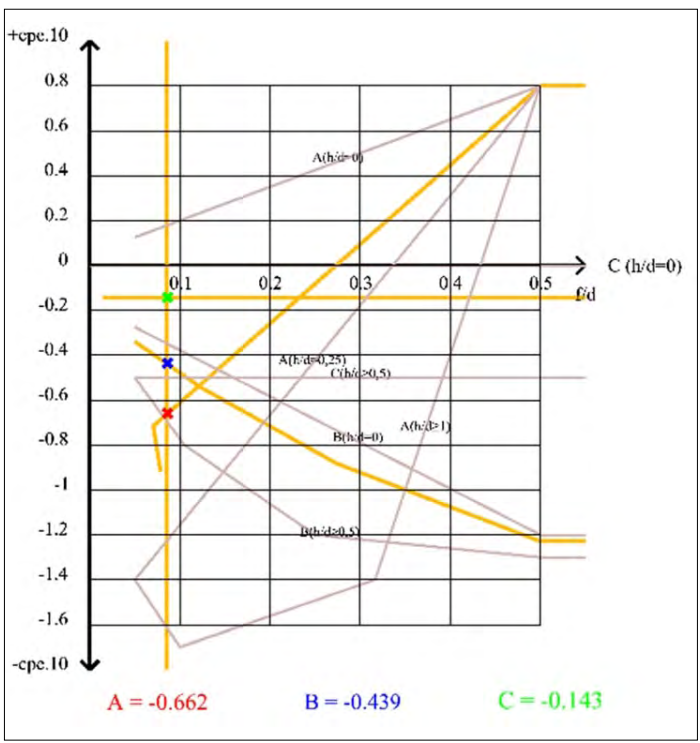

8. ábra. A nyomási tényezők ajánlott értékeit meghatározó függvény. 2. \& 3. eset

Ez természetesen több szempontból is erősen vitatható. Logikusabb viszont a vizsgált szerkezetet egy kupolának tekinteni (egy gömb felületére történő illeszkédéséből adódóan). Ez esetben a szabvány relatív körülményes módon (8. ábra) 3 karakterisztikus értéket ad meg, az épület ereszmagasságának, tetőmagasságának és átmérőjének függvényében.

A szél irányával párhuzamos síkok által kijelölt metszetkörök mentén az A, B és C értékek közötti zónák lineáris interpolációval becsülhetőek, így a 9. ábrán látható alábbi értékek vehetőek fel.

Az alaprajzi komplexitás következtében azonban ez szintén vitatható. Amennyiben a tetőszer- 


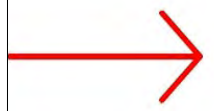

$$
A=-0.662
$$

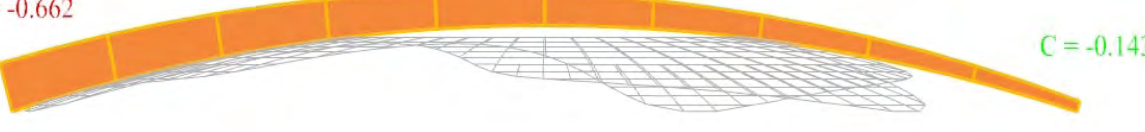

9. ábra. A nyomási tényezők alapján kigenerált diagram

kezetet úgy tekintjük, hogy a teljes felület köré írt körre vizsgáljuk a nyomási tényezőket (10. ábra), akkor maximális szívást csak a széltámadta oldal legközelebbi pontjainál feltételezünk:

Indokoltabb több szegmensre bontani a szerkezetet, azaz több részfelület köré írt kör esetére adjuk meg a nyomási tényezőket (11. ábra). Ez esetben értelemszerűen különböző átmérőjű részszerkezeteket kell feltételezni.

A szerkezet komplexitásából adódóan természetesen a mértékadó szélirány meghatározása is vizsgálandó témakör a teljes szerkezet méretezését tekintve, ami minimálisan 6 szélirányt jelent. Azonban jelen tanulmány csak arra az esetre tér ki, amikor a széltámadta oldalhoz legközelebbi rész egyben a legalacsonyabb a tetőmagasságú is, ugyanis kimondottan a tetőszerkezet szempontjából ez bizonyult mértékadónak. Ezt igazolja a 12. ábra is, melyen az előzőkhez hasonló módon felvett nyomási értékek láthatóan $60^{\circ}$-kal elfordultak szélirány esetén.

A homlokzatra ható szélterhek vizsgálata esetén szintén csak egy sajátos, intuitív elv mentén különíthetőek el a szélzónák, mivel a szabvány csak függőleges és téglalap alapterületű falak esetén nyújt útmutatást. Az nyilvánvaló, hogy minimum 3 típusú zóna elkülönítése indokolt: a szélre merőlegesnek tekinthető széltámadta oldalak, a szélárnyékos oldalak, illetve a szívott oldalsó szakasz. Mivel a burkolat geometriája kiszerkesztésre került parametrikusan, az így képzett paneleket tekinthetjük direkt teherátadó felületeknek is. Minden egyes panelt kettéosztva háromszögek keletkeznek, melyek már egy olyan síkot definiálnak, aminek a normál vektora alapján eldönthető, hogy a szélirány vektorára inkább „merőleges”, vagy inkább „párhuzamos” az adott panel, azaz a két vektor által meghatározott szög $45^{\circ}$ alatt vagy a fölött van (13. ábra).

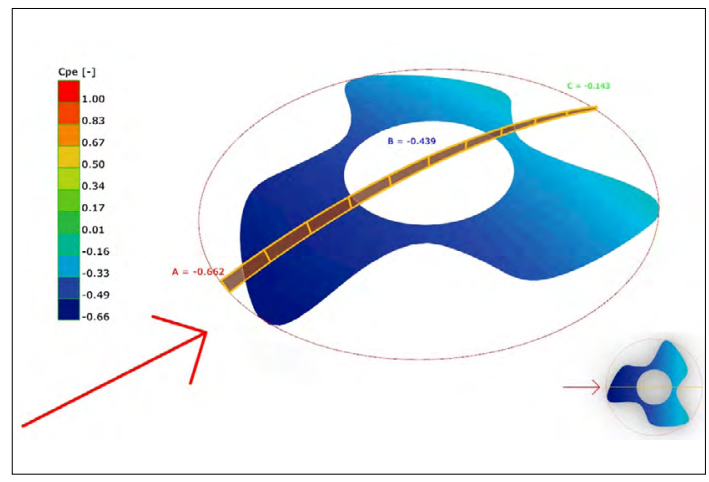

10. ábra. Nyomási tényezők a tetőn. 2. eset

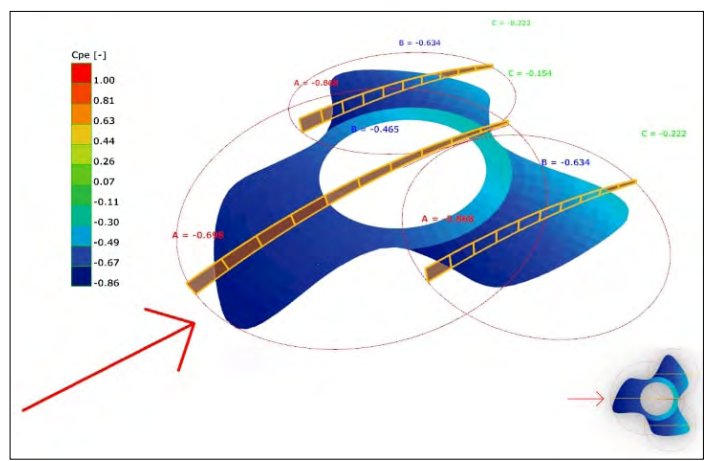

11. ábra. Nyomási tényezők a tetőn. 3. eset

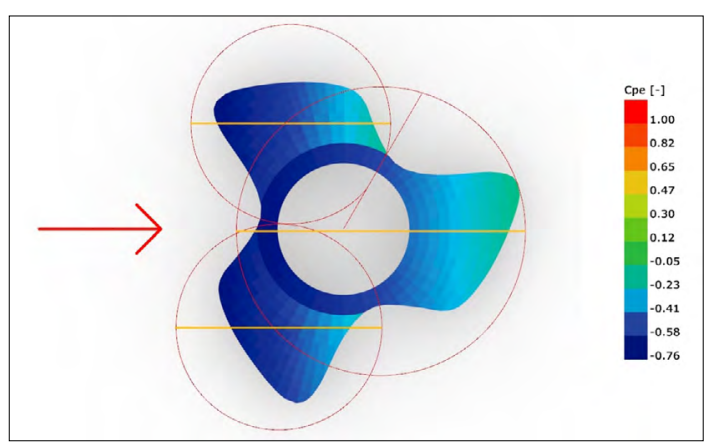

12. ábra. Nyomási tényezők a tetőn. 3. eset. $60^{\circ}-\mathrm{kal}$ elfordult szélirány esetén 


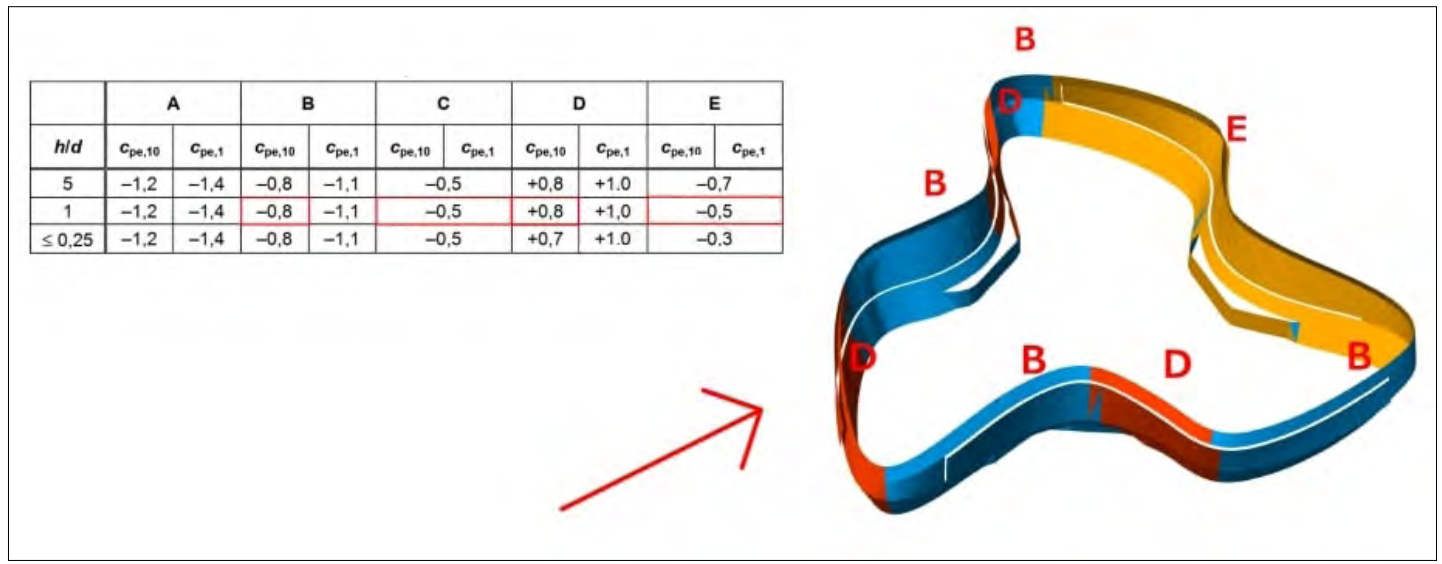

13. ábra. Nyomási tényezők a homlokzaton

\section{Szélszimuláció}

A numerikus folyadékdinamika (CFD - Computational Fluid Dynamics) a folyadékok mechanikájának egy ágazata, amely széles körben használt szimulációs módszerek alapját képezi. Több szakterületen is használatos, mint például az aerodinamika, természettudományok, időjárás-szimulációk stb. A különböző levegő-, folyadék-, hő- vagy éppen gázáramlási analízisekhez több számítógépes eszköz/eljárás létezik.

Az OpenFOAM [7] (Open Source Field Operation and Manipulation) egy ilyen jellegü, ingyenesen elérhető numerikus folyadékdinamikai számításokra) alkalmas C++ eszköztár (14. ábra). Lényegében olyan applikációk készíthetőek és hajthatók végre általa, melyekkel különböző áramlási közegeket és környezeteket szimulálhatunk. Alapvetően két fő létrehozható applikációtípust kategorizálhatunk. A megoldó (solver) típusú applikációk konkrét szilárd vagy folyékony test mechanikai problémák megoldására alkalmasak, míg a segédprogramok az adatkezelés során használhatóak.

Egy CFD alapú szimuláció előkészítéséhez az alábbi fő lépéseket különíthetjük el:

- bemeneti paraméterek megadása (a torlónyomás csúcsértékének megfelelő szélsebesség

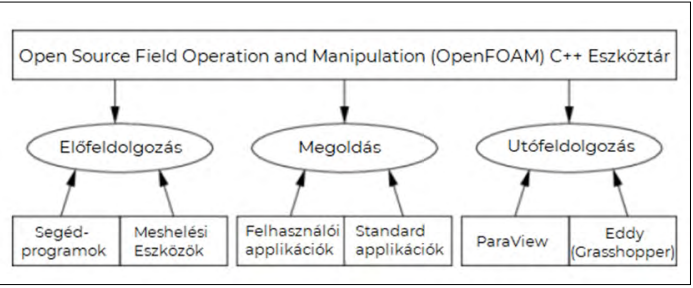

14. ábra. Az OpenFOAM eszköztárának felépitése $v_{p}(z)$, szélirány, érdességi hossz $z_{0}$, az áramlási közeg geometriai peremfeltételei [8] stb.), - elő-hálógenerálási folyamatok („előmeshelés”), - turbulenciamodell kiválasztása, - solver (megoldóalgoritmus) kiválasztása.

Az effektív szélszimuláció előtti leglényegesebb feladat a vizsgált épület és a körülötte lévő áramlási tartomány megfelelő végeselemre bontása. Ezt hálógenerálásnak vagy meshelésnek nevezzük, és bizonyos kritériumoknak kell megfelelnie az érvényes és következésképpen pontos megoldás vagy eredmény biztosításához. Az alapvető vagy előzetes hálógenerálást végezhetjük manuálisan, ami jelen tanulmány esetén Grasshopperen belül kialakított elvek alapján történt, annak érdekében, hogy a kinyert felületi nyomásértékek a megfelelő pozíciókban álljanak rendelkezésünkre az igénybevétellé konvertáláskor (15. ábra). Továbbá ezáltal szabályozhatjuk a geometria és ennek következtében a megoldandó parciális differenciálegyenletek bonyolultságát, az egyszerüségre törekedve, de mindvégig szem előtt tartva a várható fizikai viselkedést.

Az OpenFOAM nagy előnye, hogy bármely futtatás során ellenőrzi, hogy az előháló megfelel-e az érvényességi korlátozásoknak, hiba esetén kijavítva azt, majd a megadott kívánt hálóméretek alapján kialakítja a végleges hálót, amely úgynevezett tömbökre osztva tartalmazza a vizsgálandó közeget, illetve a „meshelt” épületet.

A különböző turbulenciamodellek és megoldóalgoritmusok vagy solverek mind sajátos elvek mentén feltételezik az áramló közeget és a benne lévő testeket. A leggyakrabban [9] és ez esetben is alkalmazott turbulenciamodell a $k$ kinetikus energia és az $\varepsilon$ energiaeloszlási sebesség parciális differenciálegyenleteit oldja meg $(k-\varepsilon)$, míg sol- 


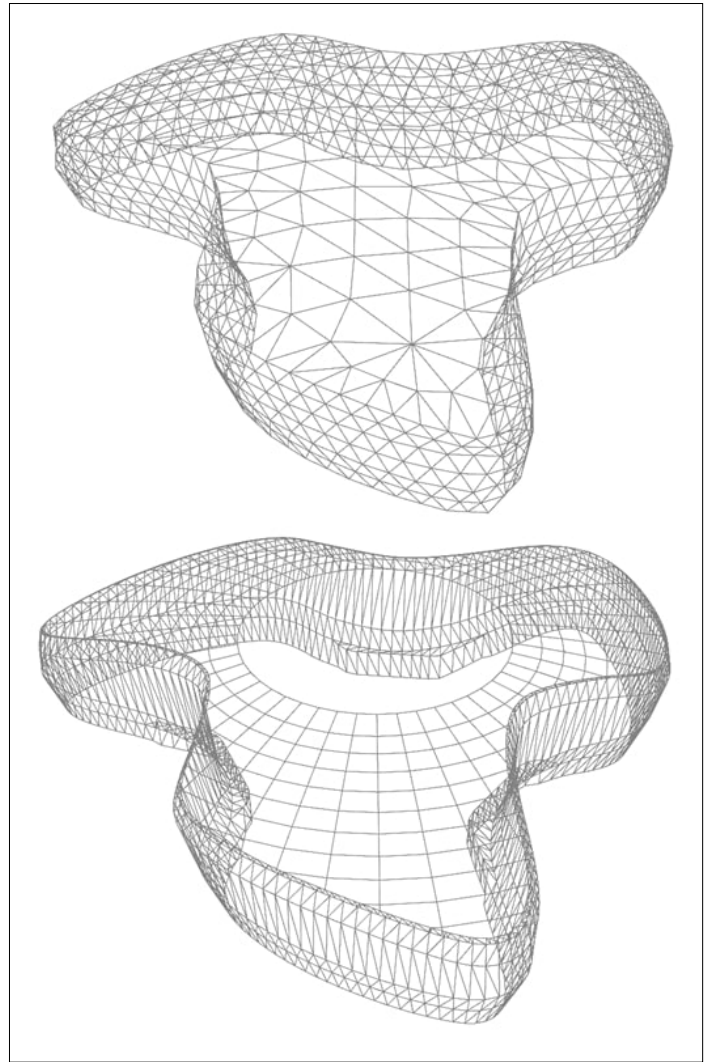

15. ábra. Az előháló generálásának eredményei

verként a SimpleFoam nevü (SIMPLE = Semi-Implicit Method for Pressure Linked Equations) lett kiválasztva. Ez esetben a szimuláció az alábbi körülményeket feltételezi:

- összenyomhatatlan, merev testek,

- turbulens áramlás,

- nincs fizikai idő, azaz kvázistatikus nyomást kapunk eredményképpen.

Az OpenFOAM futtatása Grasshopperen keresztül is vezérelhető. Így egy sokkal felhasználóbarátabb felületen alakíthatóak ki szimulációs modellek, melyek ezáltal egy parametrikus rendszer részét is képezhetik. A leggyakrabban használt ilyen bővítmények a Butterfly (Ladybug Tools), illetve az Eddy [10], melyet jelen tanulmány is alkalmaz. Az Eddy eszköztára egy teljes szimuláció felállításához szükséges parancsokat tartalmazza.

Numerikus folyadékdinamikai analízisek elvégzése és ezáltal a szélterhek szimuláció útján történő meghatározása a tartószerkezet tervezői gyakorlatban nem mindennapos. Így indokolt egy előzetes vizsgálat, egy geometriailag szabályos

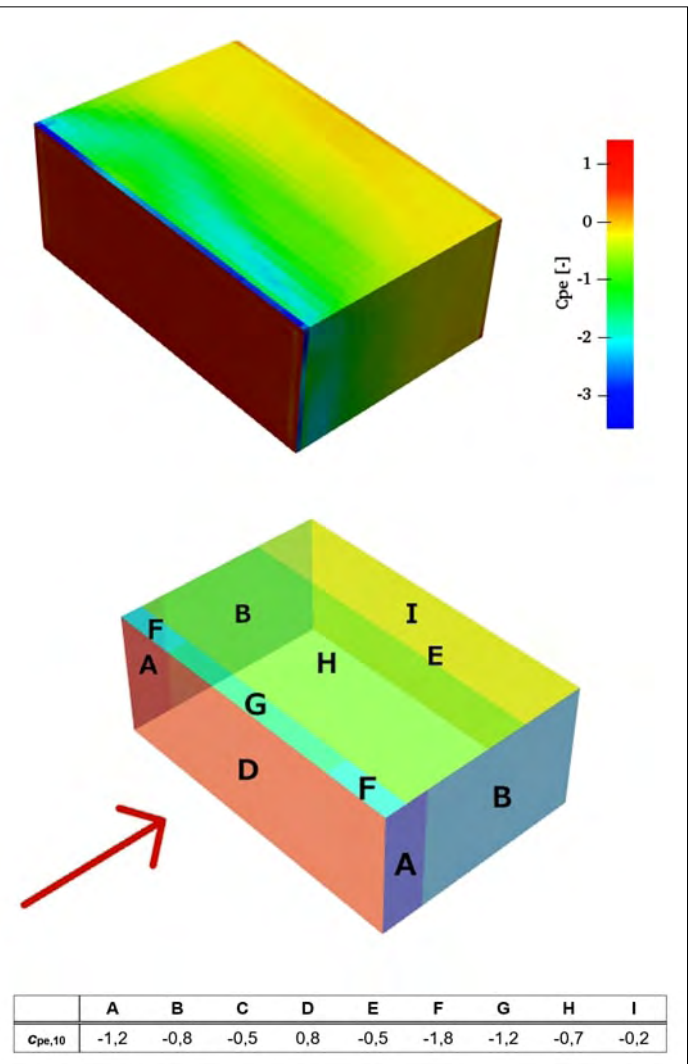

16. ábra. A „csarnokszerkezet” nyomási tényezői szimuláció alapján (felül) és a szabvány alapján (alul)

épületen (téglalap alapterületü, függőleges falú, lapos tetőszerkezetű). Ez alapján egyértelműen szembetűnő a szabvány által javasolt értékek „burkoló” szándéka, azaz az elkülönített zónák a maximális nyomásértékeket feltételezik egységesen, míg a szimuláció által kimutatható a valós nyomásváltozás a felületen, figyelembe véve az intenzívebb, lokális hatásokat (16. ábra).

Érdekességképpen amennyiben tartószerkezeti szempontból egy keretszerkezetként, azaz egy tipikus acél csarnokszerkezetként tekintünk az épületre, jól kimutatható a szerkezet viselkedésének különbsége a két módszer alapján. Az elmozdulások tekintetében a mértékadó pozíciók esetében (oszlopvég, főtartó középpont) 50-80\%-kal nagyobb értékek is előfordulhatnak a szabvány által javasolt módszerek esetében. Amennyiben méretezni kívánnánk a szerkezetet, körülbelül 10-20\%-os kihasználtsági különbségeket tapasztalhatunk a szimulációs módszer javára. Az eltérések mértéke attól függ, hogyan értelmezzük az adott, pontszerűen (a „meshek” sarokpontjainál) 
kinyert nyomásértéket, azaz hogyan konvertáljuk felületi teherré egy statikai analízis során. Egy statikai modell esetén a legkézenfekvőbb teherátadó felületeket definiálni (hasonlóan a szabvány által javasolt zónákhoz), melyeken a terheket definiálhatjuk a hozzá tartozó nyomáspontok átlaga vagy a maximális érték alapján egységes vagy éppen változó intenzitásúként (17. ábra).

Az egyszerű csarnokszerkezet szimulációs metodológiáját alkalmazva a tanulmányozott szabadformájú szerkezet szélszimulációs eredményei már jelentősebb szórást mutattak a pontszerűen kinyert nyomások szélsőértékeit vizsgálva (legnagyobb szívás és nyomás). Emellett feljegyzésre kerültek a különböző modellek hálógenerálási paraméterei, aminek az OpenFOAM elvégezte a végleges hálógenerálást, illetve az adott szimuláció futtatási időigénye. Ez alapján kimutatható, hogy kiemelt fontossággal bír a háló „sűrűsége” a lokális nyomáskoncentrációk vizsgálatakor és természetesen az időigény szempontjából is. Az 1. táblázat négy kiemelt szimuláció eredményeit foglalja össze, az utolsó, „legsűrűbb” meshelés eredményeit bemutató ábrával összhangban (18. ábra).

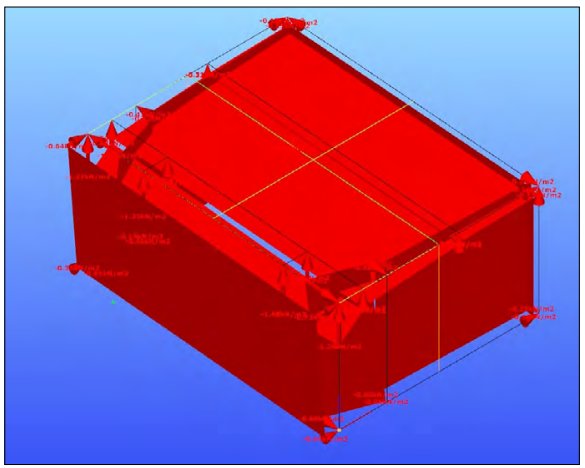

17. ábra. Az eredmények változó intenzitású felületi teherként értelmezve egy statikai analízis során (ConSteel)
1. táblázat. A szimulációk eredményei

\begin{tabular}{|c|c|c|c|c|c|c|}
\hline $\begin{array}{c}\text { Tömb } \\
\text { méret } \\
{[\mathrm{m}]}\end{array}$ & $\begin{array}{c}\begin{array}{c}\text { Véges- } \\
\text { elem } \\
\text { méret }\end{array} \\
{[\mathrm{m}]}\end{array}$ & $\begin{array}{c}\text { Min } \\
\text { Cpe } \\
{[-]} \\
\end{array}$ & $\begin{array}{c}\text { Max } \\
\text { Cpe } \\
{[-]} \\
\end{array}$ & $\begin{array}{c}\begin{array}{c}\text { Hálóge- } \\
\text { nerálás } \\
\text { futás- } \\
\text { ideje } \\
\text { [min] }\end{array} \\
\end{array}$ & $\begin{array}{c}\text { Szimu- } \\
\text { láció } \\
\text { futás- } \\
\text { ideje } \\
\text { [min] }\end{array}$ & $\begin{array}{c}\begin{array}{c}\text { Utófel- } \\
\text { dolgozás } \\
\text { futás- } \\
\text { ideje } \\
\text { [min] }\end{array} \\
\end{array}$ \\
\hline 10 & 1 & $-2,02$ & 0,57 & 2 & 4 & 3 \\
\hline 10 & 0,5 & $-2,26$ & 0,43 & 4 & 5 & 3 \\
\hline 5 & 0,5 & $-1,75$ & 0,46 & 10 & 35 & 5 \\
\hline 2 & 0,5 & $-5,72$ & 0,83 & 16 & 50 & 12 \\
\hline
\end{tabular}

\section{Következtetések}

A tanulmányban bemutatottak alapján megfigyelhető a parametrikus tervezésben rejlő igazi potenciál, főként a sokoldalúságra való tekintettel. Gyakorlatilag bármilyen tervezési folyamat során jelenthet előnyt egy parametrikusan kialakított metodológia használata, azonban fontos kiemelni, hogy egy ilyen jellegű rendszer kiépítése időigényes feladat. Ennek tudatában megfelelő tapasztalat szükséges ahhoz, hogy megbecsülhető legyen a bevezethető hatékonyság mértéke. Mindemellett érdemes nyomon követni a parametrikus tervezés mögött álló fejlesztői réteget, amely folyamatosan új eszközök megjelenésén dolgozik, ezáltal az automatizálás iránti igény egyre könynyebben kielégíthető. Valójában csupán a hétköznapi feladatokban rejlő rutinszerüséget kell felismerni, és kis ráfordítással rendkívül hatékonnyá tehető a munkavégzés. Indokolt esetben komplex feladatok elvégzéséhez is érdemes kialakítani egy ilyen jellegű rendszert, főleg ha az optimizálás a cél (lévén, hogy alapvetően ennek érdekében fejlesztették ki a Grasshoppert [11]).

A szélszimuláció témaköre viszont sokkal bonyolultabb. A tapasztalat alapvetően azt mutatja, hogy a CFD alkalmazható ugyan ipari felhasználású széltehervizsgálatok elvégzésére,

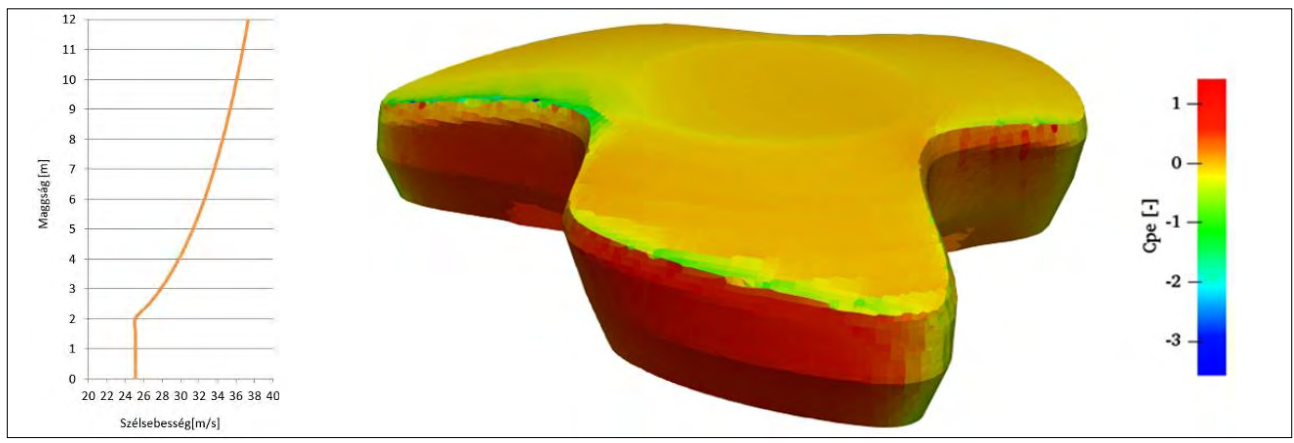

18. ábra. A szerkezetre ható szélprofil (bal) és a szimuláció szerinti nyomástényezők (jobb) 
de megbízhatósága igen kérdéses. Főleg annak következtében, hogy komoly áramlástani szaktudást igényel, és nem megfelelő használat esetén abszolút ellentmondásos eredmények állíthatóak elő. Ennek ellenére indokolt esetben kiválthatja egy parametrikus környezetben felépített szimuláció a szabvány által javasolt módszereket, főleg amennyiben a vizsgált szerkezet kialakítására nehezen erőltethetőek rá az egyszerűbb koncepció mentén meghatározott alaki vagy nyomási tényezők. A bemutatott szerkezet esetén kijelenthető, hogy a szabvány által javasolt módszerek alapján meglehetősen eltérő nyomásértékek vehetőek fel. A szerkezet legkritikusabb zónái a széltámadta oldalak szívott tetőperemei, ahol a szabvány alapján három különböző módon felvett nyomási tényezők értékei rendre -0,66, -0,86, -1,2. Ezzel szemben a szimuláció alapján pontosabban kimutatható, hogy valójában a lokális nyomáskoncentrációk esetén a fenti értékeknél akár nagyobb, -2 körüli tényezők is kimutathatóak, de átlagosan véve -1 körülre tehető a szélszívás értéke az említett zónában, azonban ez kisebb területre igaz, mint ahogyan a szabvány előírja.

Természetesen teljes mértékben nem javasolt ezekre az adatokra hagyatkozni, de egy általános képet és egyben útmutatót mindenképpen adhat a szerkezettervező mérnök számára a nyomáseloszlás és ezáltal az épületre ható szélterhek meghatározásakor.

A szabvány és a számítógépes szélszimuláció közötti arany középutat a laboratóriumi szélcsatorna-vizsgálatok jelenthetik, viszont itt is ki kell emelni néhány hátráltató tényezőt. Az elsődleges szempont itt is a szaktudás és a technológia, amely főleg a régiónkban kevés esetben biztosított, épület-szélszimulációs értelemben. Mivel egy relatív ritka igényről beszélünk, ugyanis kevés komoly beruházás indokolja az ilyen jellegű vizsgálatokat, így nem létezik know-how, vagy akár az adatközlésre vonatkozó protokoll egy ilyen jellegű feladat esetén a laboratórium és a megbízó között. Egy további lényeges szempont egy szélcsatorna-vizsgálat esetén a ráfordítandó idő mennyisége, amely a piac gyors tempójához kevés esetben zárkózik fel, mivel egy szélszimulációs makett megépítése önmagában akár hetekig is eltarthat, főleg ha különböző építési fázisok szimulálása érdekében egy moduláris modellre van szükség. Ezt követően a mérések és az eredmények kiértékelése hasonlóan hosszú folyamat lehet, így egy teljes kísérlet időrtama akár 3-6 hónapig is elhúzódhat, míg egy komplexnek tekinthető tartószerkezet tervezése és méretezése akár hetek alatt is véglegesítődhet.
Így lényegében a tervezés kezdeti fázisáig - ahol a szabvány szerinti eljárást felülírva lehetne gazdaságosabban tervezni a szélszimulációs eredmények tudatában - sok esetben még nem áll rendelkezésre adat. Éppen ezért egy szabadformájú szerkezet tervezésének korai fázisában érdemes megfontolni a szélszimulációs módszerek alkalmazását. Ezt megelőzően természetesen további kísérletek és tanulmányok indokoltak egy validált és megbízható metodológia kialakításához.

\section{Szakirodalmi hivatkozások}

[1] Akos G., Parsons R.: Foundations. The grasshopper primer third edition, 2006.

https://issuu.com/pabloherrera/docs/mode_lab_ grasshopper_primer_third_e/3

[2] Szalai J., Juhász M. I., Kis Á.: Eingangshalle Hungexpo-parametrische Entwurfs, Berechnungs- und Nachweismethoden/Hungexpo elöcsarnok - parametrikus tervezési, számítási és ellenőrzési módszerek. BIM - Building Information Modeling, 2020 november/A61029, 106-112.

https://issuu.com/ernst-und-sohn/docs/bim2020_ web/1?ff

[3] Kis Á.: Acélszerkezetek tervezése és szélszimulációja parametrikus környezetben. Diplomamunka, Kolozsvári Műszaki Egyetem, 2020.

[4] Arendt E.: Szabadformájú rácsos acél felületszerkezet paraméteres vizsgálata. Diplomamunka, Budapesti Műszaki Egyetem, 2020.

[5] Văcăreanu R.: Cod de proiectare. Bazele proiectării și acțiuni asupra construcțiilor. Acțiunea vântului (Revizuire NP 082-04. Comentarii, recomandări de proiectare și exemple de calcul). Universitatea Tehnică de Construcții București, 2012.

[6] MSZ EN 1991-1-3:2005: Eurocode 1: A tartószerkezeteket érö hatások, 1-4. rész: Általános hatások, Szélhatás.

[7] OpenFOAM - The open source CFD toolbox. (letöltve: 2021. február 17.).

https://www.openfoam.com/

[8] Holmes J. D.: Wind Loading On Structures. S. Press, Ed., New York, USA: Taylor \& Francis e-Library, 2007.

[9] Nagy-György T., Boros J., Crișan A.: Egy szélérzékeny tetőszerkezet számítási érdekességei/Computational curiosities of a wind-sensitive roof structure. XXIV. Nemzetközi Építéstudományi Online Konferencia - ÉPKO, 2020.

http://ojs.emt.ro/index.php/EPKO/article/ view/246/191

[10] Eddy - Airflow and Microclimate Simulations for Rhino and Grasshopper (letöltve: 2021. február 17.). https://www.eddy3d.com/

[11] Rutten D.: Evolutionary Principles applied to Problem Solving. 2011. (letöltve: 2021. február 17.). https://ieatbugsforbreakfast.wordpress. com/2011/03/04/epatps01/ 